\title{
Inhibition of AA 2024-T3 Corrosion in Alkaline NaCl Solution by Compound Sodium Dodecylbenzenesulfonate and Cerium Chloride
}

\author{
Yu Zuo, Biner Zhou and Yuming Tang ${ }^{*}$ \\ Beijing Key Laboratory of Electrochemical Process and Technology for Materials, \\ Beijing University of Chemical Technology, Beijing 100029, China \\ *E-mail: tangym@mail.buct.edu.cn
}

doi: $10.20964 / 2017.12 .58$

Received: 1 July 2017 / Accepted: 29 September 2017 / Published: 12 November 2017

\begin{abstract}
The synergic corrosion inhibition of AA 2024-T3 by sodium dodecylbenzenesulfonate and cerium chloride in $0.01 \mathrm{~mol} / \mathrm{L} \mathrm{NaCl}$ solution ( $\mathrm{pH} \mathrm{10)}$ was studied by potentiodynamic polarization, XPS, EDS and SEM. In presence of $0.1 \mathrm{~g} / \mathrm{L} \mathrm{CeCl} \mathrm{Cl}_{3}+0.28 \mathrm{~g} / \mathrm{L} \mathrm{SDBS}$ inhibitors, both the general corrosion and pitting corrosion were effectively inhibited. A compound inhibition film including the oxides and hydroxides of aluminum and cerium, the organic rare earth compound $\mathrm{Ce}(\mathrm{DBS})_{3}$ and the corrosion product $\mathrm{Al}(\mathrm{DBS})_{3}$ were formed on the surface, which provided good corrosion protection to the AA substrate. As the immersion time was extended, the passive state remained stable while the inhibition effect for pitting corrosion decreased to some extent due to the formation of pits around the $\mathrm{Cu}$-rich phases, induced by the galvanic effect between the $\mathrm{Cu}$-rich phases and the aluminum substrate.
\end{abstract}

Keywords: AA 2024-T3; Inhibition; SDBS; $\mathrm{CeCl}_{3}$; Pitting corrosion

\section{FULL TEXT}

(C) 2017 The Authors. Published by ESG (www.electrochemsci.org). This article is an open access article distributed under the terms and conditions of the Creative Commons Attribution license (http://creativecommons.org/licenses/by/4.0/). 